\title{
LEITURAS PLATÔNICAS, ANTIGAS E SEMPRE NOVAS
}

TARRANT, Harold; BATZLY, Dirk. Reading Plato in Antiquity. London: Duckworth, 2006.

Gabriele Cornelli* gabrielec@uol.com.br

Resultado de um "pequeno simpósio" sobre a interpretaçao de Platão, que teve lugar na Universidade de Newcastle (Austrália) no mês de julho de 2002, a obra coletiva é organizada por dois importantes estudiosos de Platão da área anglo-saxônica, Harold Tarrant e Dirk Batzly. Os autores se propõem a uma discussão em nada genérica ou incerta sobre a filosofia platônica e suas múltiplas relações. Inicialmente, enfocam as relações com suas leituras, isto é, com os autores que fundamentam o esforço filosófico de Platão e da Academia, e, em seguida, com seus leitores, ou seja, com todos aqueles que, já no mundo antigo, fizeram de Platão e da filosofia platônica seu texto-base de freqüentação assídua e reflexão teórica.

No interior do quadro habilmente desenhado por autores como John Dillon (sobre a tradição "pedante" dos comentários médio-platônicos), Luc Brisson (sobre a doutrina dos degraus da virtude em Porfírio), Lloyd Gerson (sobre a visão neoplatônica da harmonia entre Platão e Aristóteles), e outros, de Aristóteles aos estóicos, até o interesse por Platão pelo pensamento cristão bizantino, o quadro das lectiones é generosamente amplo e detalhado.

* Professor do Departamento de Filosofia, UnB, Brasília, Brasil.

KRITERION, Belo Horizonte, nº 116, Dez/2007, p. 497-498. 
O leitor de Platão e de sua tradição poderá encontrar, no desenvolvimento dos textos, verdadeiras preciosidades: entre elas, especialmente, as referências às atividades de Apuléio e Plutarco de Queronéia, docentes profissionais de Platão, as citações diretas ao texto platônico na obra de Galeno e a descrição dos diversos e complexos impactos que a obra platônica teve nas margens africanas do Mediterrâneo, entre Fílon, Plotino e os autores cristãos.

Merece uma indicação especial o artigo de Hayden Ausland, "The mathematics of justice", que procura nas leituras pitagóricas de Platão os sentidos de uma teoria da justiça diretamente fundada sobre o conceito matemático de igualdade.

Uma obra bem-vinda, pensada para um leitor atento à história da tradição da obra platônica, sempre em busca de seus percursos. Uma obra que, enfim, não renuncia à gentileza de um favor especial a este mesmo leitor: aquela de oferecer, no final, um Index Locorum e de Nomes Antigos, que, acreditamos, deveria ser obrigatório em todas as publicações, mesmo estas organizadas a partir de diversas contribuições, e que se queiram úteis e, de fato, utilizáveis como fontes de pesquisa ainda por um longo tempo. 